\title{
CHANGES IN LAND USAGE OF RURAL AREAS IN SUBURBAN AREA OF KATOWICE CONURBATION
}

DOI: http://dx.doi.org/10.18509/GBP.2018.28

UDC: $332.122: 338.43(438)$

\section{Marlena Dyszy}

University of Silesia, Faculty of Earth Sciences, Department Economic Geography, Poland

\begin{abstract}
The purpose of the elaboration is to indicate the changes occurring in the usage of land of rural areas. The investigated area is located in the south of Poland and includes eight rural municipalities in the suburban area of Katowice conurbation. The spatial scope of the examination concerns 2002, 2008 and 2014. The influence of the Katowice conurbation acquires different spatial forms. One of the manifestations are the changes of land usage. Rural areas of favourable conditions for the development of agriculture are subjected to the process of urbanization to the lesser extent in relation to areas of unfavourable conditions for agriculture. A decrease of the participation of land used agriculturally occurs, to the benefit of the lands of residential, service-related and industrial usage. The entire scope of research is subject to the city expanding over the suburban area. The dynamism of these changes varies in time. The elaboration allows to specify the direction of changes of the usage of land on the investigated rural areas.
\end{abstract}

Key words: land usage, rural area, agriculture, suburban area, suburbanization.

\section{INTRODUCTION}

Intense socio-economic changes occur in the area of interactions of large cities and municipal clusters. Agriculture which has theretofore developed well is frequently replaced with other business activities related to services, minor industry and tourism. Municipal and suburban areas reveal high dynamism in the scope of land usage changes in Poland. In the field of general surface, the proportion of usable agricultural land has been decreasing to the benefit of an increase of built-up areas which are predominantly intended for residential housing, as well as for industrial, service-based and communication purposes. The basic forms of land usage functions are being gradually changed [4]. The development of municipal areas leads not only to spatial changes, but also to functional ones in the light of rural areas, particularly in the close vicinity thereof [24], [6]. Rural areas located in the vicinity of big towns, altogether with socio-economic development, undergo the influence of urbanization to a major extent. Apart from economic, social and cultural changes, also the changes of spatial organization of certain settlement units and bigger areas occur. Most frequently they constitute transient forms between city and village [1]. Suburban areas predominantly reveal non-agricultural functions, whereas the agriculture itself does not constitute the major source of the income of population, whereas farmsteads are of minor proportion of the general area [13]. The development of rural areas manifests itself through changes occurring in the structure of land usage. The areas that have so far been predominantly agricultural are - with intensifying urbanization processes - starting to diversify, the result of which is the occurrence of non-agricultural functions. Consequently, various functions such as, inter 
alia, housing, services, industry, tourism, begin to prevail. Spatial urbanization of villages is primarily and predominantly based on the changes of land usage (a decrease of rural areas), physiognomy of development, morphology of settlement units, as well as equipping with facilities. Rural areas, in terms of landscape, are beginning to imitate municipal areas [12]. Socio-economic changes which occurred after 1989 did not solely concern Poland, but also other European states. The changes of the development of rural areas have occurred. Agricultural production is maintained on the areas of favourable conditions for the development of agriculture, whereas rural areas around cities reveal the development of residential housing and business activities, with a simultaneous decrease of agricultural areas [5]. Intensified construction activities in suburban areas has not only been observed in Poland, but also in Slovakia [15], Hungary [21] and Czech Republic [14].

The purpose of the elaboration is the indication of changes in land usage in the background of a highly urbanized and complex urban unit of conurbation. The spatial scope of the elaboration encompasses 2002, 2008 and 2014.

\section{STUDY AREA}

The spatial area of research concerns the suburban area of Katowice conurbation. This complex settlement structure is located in the central part of Silesia, in the south of Poland [22]. It embraces 54 administrative units: cities, rural-urban municipalities and urban municipalities. Three structural areas are included within: core, internal area and external one (Fig. 1). This area covers $3,775 \mathrm{~km}^{2}$ and has $2,581.2$ thousand inhabitants (for the year of 2016), whereas the core itself has 1,961.1 thousand inhabitants (75\% of the conurbation's population). The conurbation of Katowice is one of the biggest and most densely populated settlement forms in Europe [9], [18].

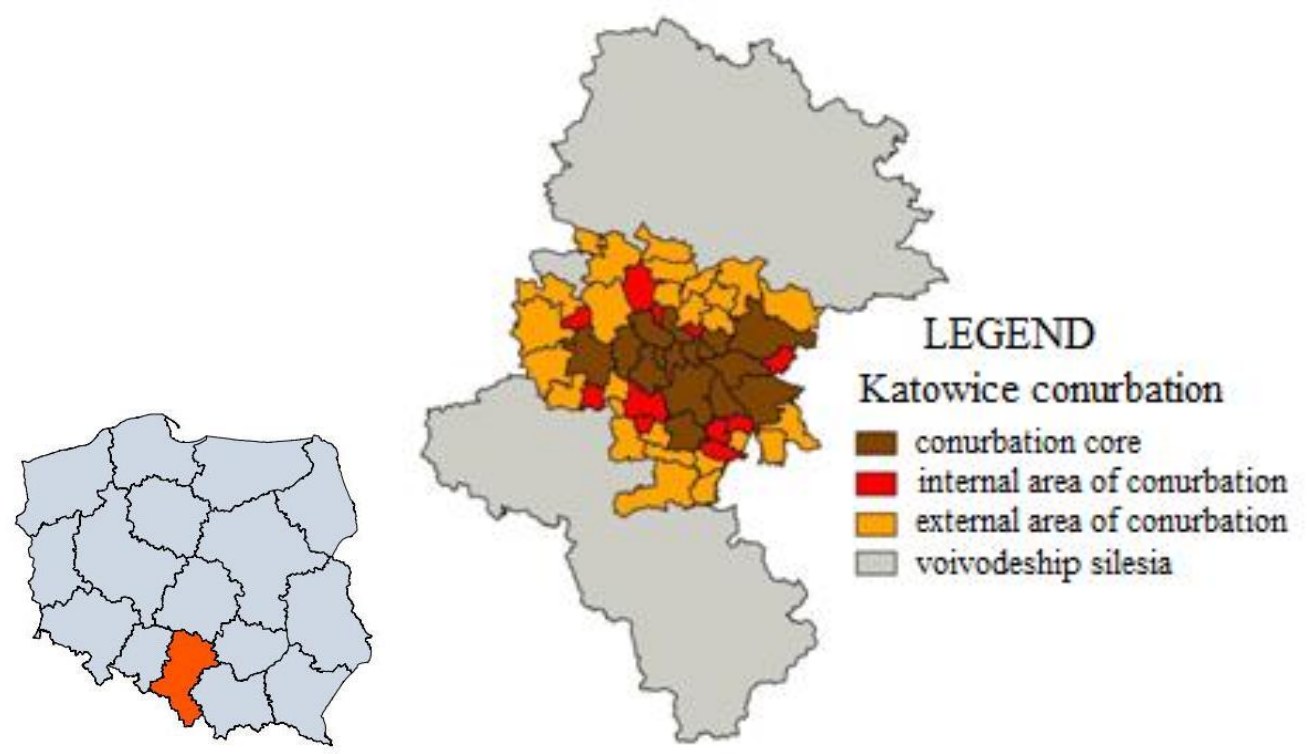

Figure 1. Location of Katowice conurbation.

Source: author's elaboration.

The area under study encompasses eight rural areas of Silesia located in the background of the conurbation of Katowice. They are incorporated in the external zone of the aforementioned settlement unit. The municipalities are: Bobrowniki, Psary, Świerklaniec, 
Zbrosławice, Gierałtowice, Wyry, Kobibór and Chełm Śląski (Fig. 2). The studied area is highly diversified internally. The analysis carried out will allow to exhibit the changes of land usage as affected by the conurbation of Katowice. Villages are located in the area of interaction of the cities of various size.

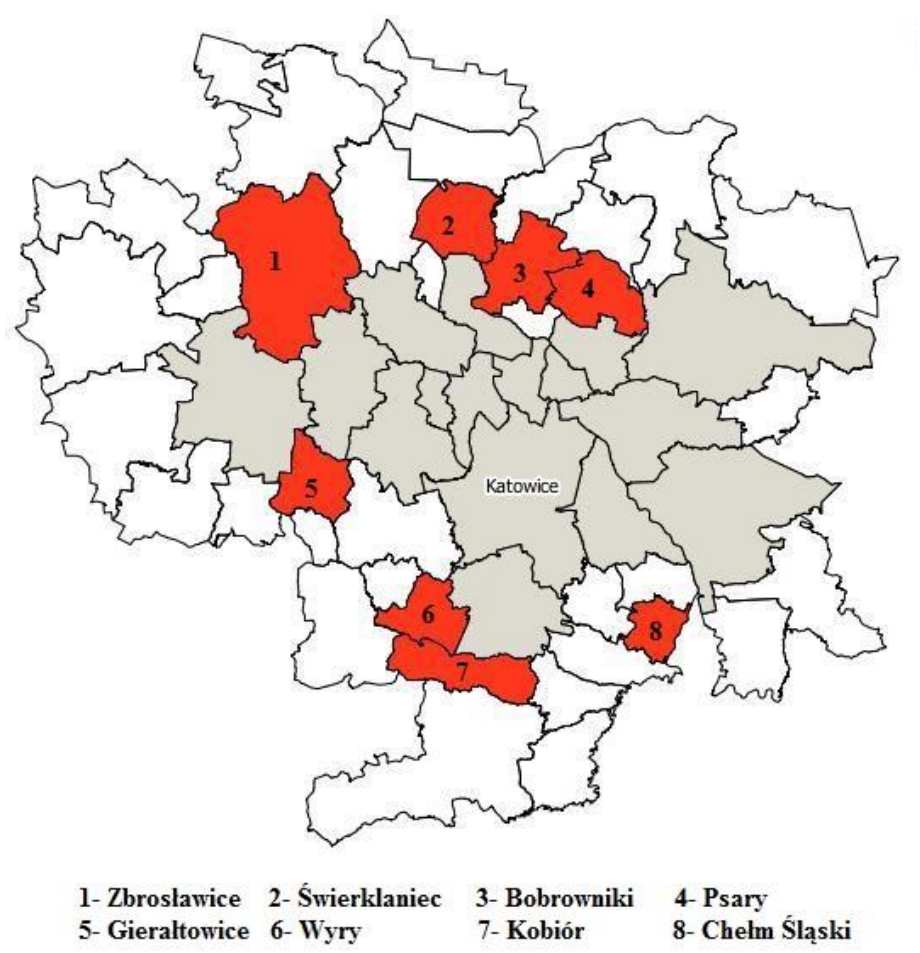

Figure 2. Examined rural municipalities in suburban area of Katowice conurbation.

Source: author's elaboration.

The conurbation of Katowice has an industry-based genesis. It has been undergoing a transformation from a mono-functional area with the dominance of mining and metallurgy region into a region of various industry branches [23]. In the 1980s and 1990s of the twentieth century, the conurbation of Katowice was characterized by an underdeveloped sector of services, as juxtaposed with other highly urbanized areas of Poland [7]. The intense restructuring of the economy - including industry - that has been occurring since 1989 allowed not only to liquidate numerous old and unprofitable working places, but also to limit agricultural production in state-owned farms and collective farms in rural areas. Socio-economic transformation has activated the development of services sector, which contributed to the increase of the number of employees in this sector. This has altered the structure to a service-economic one. The prices of land in the central cities have increased [28], which imposed certain urbanization and socio-economic processes in suburban areas, particularly in the areas of villages located in the direct vicinity thereof or well-communicated with the centre.

Silesia is the most urbanized area in Poland, as well as a region of great economic $(12.4 \%$ of GDP) and demographic (4.5 million inhabitants $-11.9 \%$ of the country's population) significance. It exhibits the highest nationwide density of population and urbanization of over $77 \%$. The total number of nearly 998 thousand inhabitants, i.e., approximately $21 \%$ of the region's dwellers, live in rural areas. This constitutes $6.8 \%$ of the rural inhabitants of Poland. The diversified development conditions of rural area stems from the various interactions of factors of a historical, natural and economic character. Such 
diversification has been intensifying in rural areas located in the domain of influence of large urban areas that are the place of non-agricultural employment.

\section{FINDINGS AND DISCUSSION LAND USAGE IN SILESIA}

Agriculture in the background of urbanized regions, suburban area to be precise, differs from agriculture in rural areas. The expansion of urbanization influences the characteristics of suburban settlements, altering local economy, production and social features of farmers [3]. Suburban areas can be characterized by specialized horticulture, purposeful plant production and animal husbandry [26]. The agriculture of Silesia exhibits extreme fragmentation of farmsteads and a low level of the concentration of land intended for farming. The favourable conditions for the development of agriculture are present of the total area of $43 \%$ of land, whereas the unfavourable ones - on the total area of $37.3 \%$ farming lands [2].

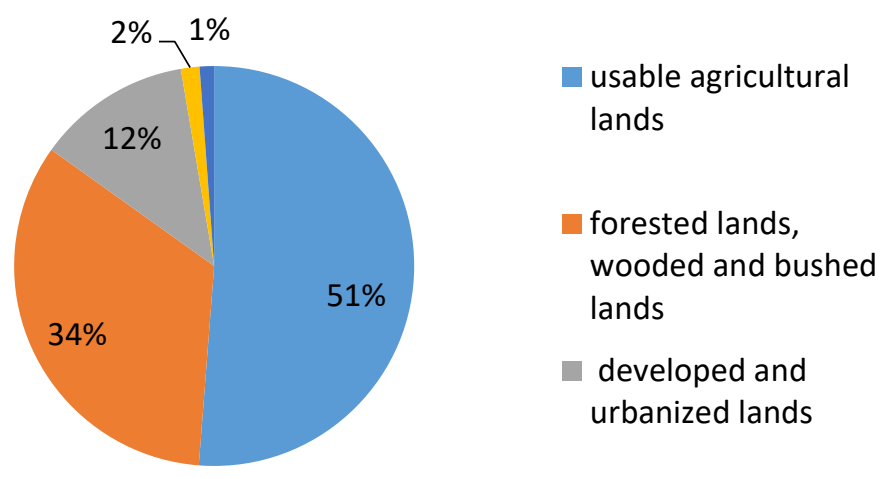

Figure 3. Structure of land usage in Silesia in 2014

Source: author's elaboration on the basis of data of Central Statistical Office.

The dominant form of land usage in Silesia are farming lands (Fig. 3). There has been a decrease of the participation thereof, namely by $4 \%$, from 43.9 thousand hectares to $51 \%$ of the total area, in 2002 - 2014. Arable lands are in majority - 72\%. In turn, forest lands, as well as wooded and bushed areas, have increased insignificantly in the general structure of land usage, reaching the total of $34 \%$ of the state. The biggest increase in 2002 - 2014 took place in developed and urbanized lands, from $9.1 \%$ to $21.4 \%$ of the total area, namely to 41.3 thousands of hectares. This gives evidence of progressing urbanization. Housing, industrial and other developed lands are incorporated to these areas. The most significant increase was recorded for housing lands, from 22.4 thousand hectares in 2002 to 47.8 thousand hectares in $2014-11.2 \%$.

\section{USAGE OF LAND IN SUBURBAN AREA OF KATOWICE CONURBATION}

The researched urban areas are characterized by a significant diversification in terms of conditions for the development of agriculture. The most favourable conditions may be found in the municipality of Zbrosławice, located in the western part of the conurbation of Katowice, where large-scale farms supplying the local, regional and national food industry are located. It is one of the ten rural municipalities of the best agricultural conditions in Silesia. This particular municipality serves a paratypical example, since in the suburban area of such major urban clusters agriculture gives way to other non- 
agricultural activities. Favourable conditions are also present is the municipalities of Świerklaniec and Gierałtowice. Large-scale farms are also present there. Of average conditions is the municipality of Wyry, whereas in the remaining municipalities, i.e. Bobrowniki, Psary, Kobibór and Chełm Śląski, the conditions are unfavourable.

Taking into account agricultural lands, a trend may be noticed which reveals a decrease of this form of land usage on the entire surface. Agricultural lands are still predominant in Psary, Zbrosławice, Gierałtowice and Chełm Śląski, being approximately $70 \%$ of the general area (Fig. 4). In Bobrowniki the total comes up to nearly 60\%, whereas in Wyry - almost 50\%. They occupy the smallest proportion of land in the municipality of Świerklaniec, approximately $25 \%$, and Kobibór, scarcely $10 \%$, which in this particular instance results from a large surface of wooded lands. Among all agricultural lands, arable lands have the highest proportion. An insignificant decrease, except for Zbrosławice, may be attributed to a decrease of pastures. The area of research exhibits a decrease in the participation of orchards and meadows.

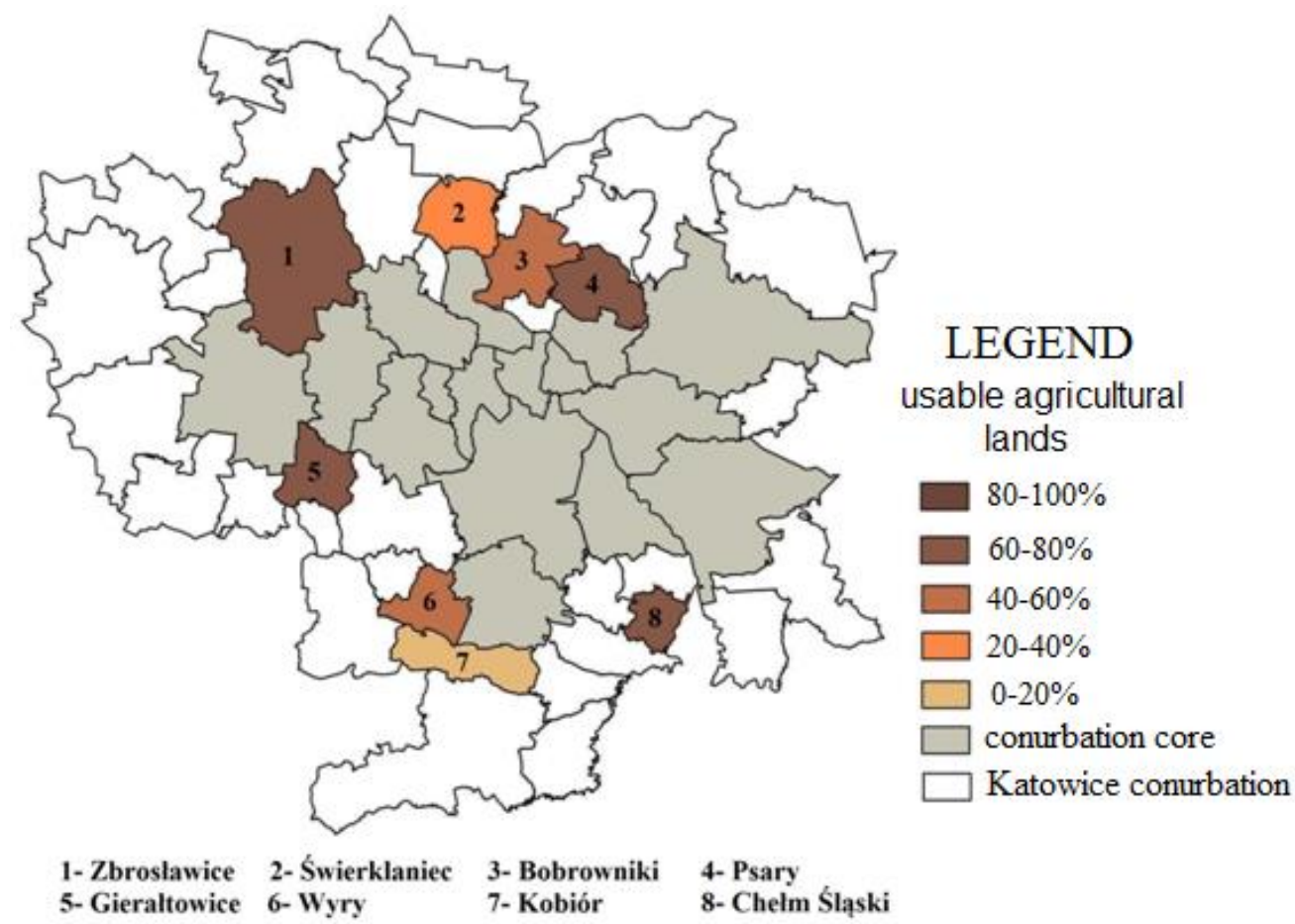

Figure 4. Participation of agricultural lands in research area, 2014

Source: author's elaboration.

The decrease in agricultural areas in the total surface indicates a gradual decay of agricultural functions in the investigated area. Agricultural activities play a major role only in the municipality of Zbrosławice. Business entities created provide specialized activities, focusing on specific areas of production, e.g., crops, vegetable farming, animal husbandry and horticulture. The diversification of activities of an agricultural character gives evidence of changes in the economic area. In Zbrosławice, the largest farmingbased business entity occupies the land of approximately 2.300 hectares, whereas the products made are sold in retail chains and EU, predominantly. There is a company that focuses on the purchase and processing of crops. It is the producer of wheat flour, rye flour, as well as semolina, wheat and rye bran. The municipality is also a location for companies offering complex agricultural services. There is a decay of small farms 
occupied with farming for own consumption and use. In the past, the investigated area was also a domain of small farming, however - in the course of years - it started to disappear.

Business activities related to farming are also present in the remaining municipalities. There is a company in Psary that is engaged in specialized gardening and farming. Świerklaniec has a number of business entities dealing with horticulture.

Analysing another category of land usage, namely wooded and forested lands, there have been certain differences in land occupation in the investigated municipalities. An increase in the total amount of green areas occurred in five municipalities: Bobrowniki, Psary, Zbrosławice, Wyry and Chełm Śląski. The remaining area exhibited a slight decrease in such lands. Simultaneously, it ought to be indicated that $85 \%$ of Kobibór is occupied by a forest basin owned by the forest division of Kobibór, due to which the remaining forms of land usage constitute but a minor area of surface (Fig. 5). Forests and wooded lands, as forest basins and parks, play a major role in Świerklaniec (45\% of land). On one hand, it results from a high participation of wooded lands, on the other - from parks of a significant recreational function for the northern part of the conurbation of Katowice.

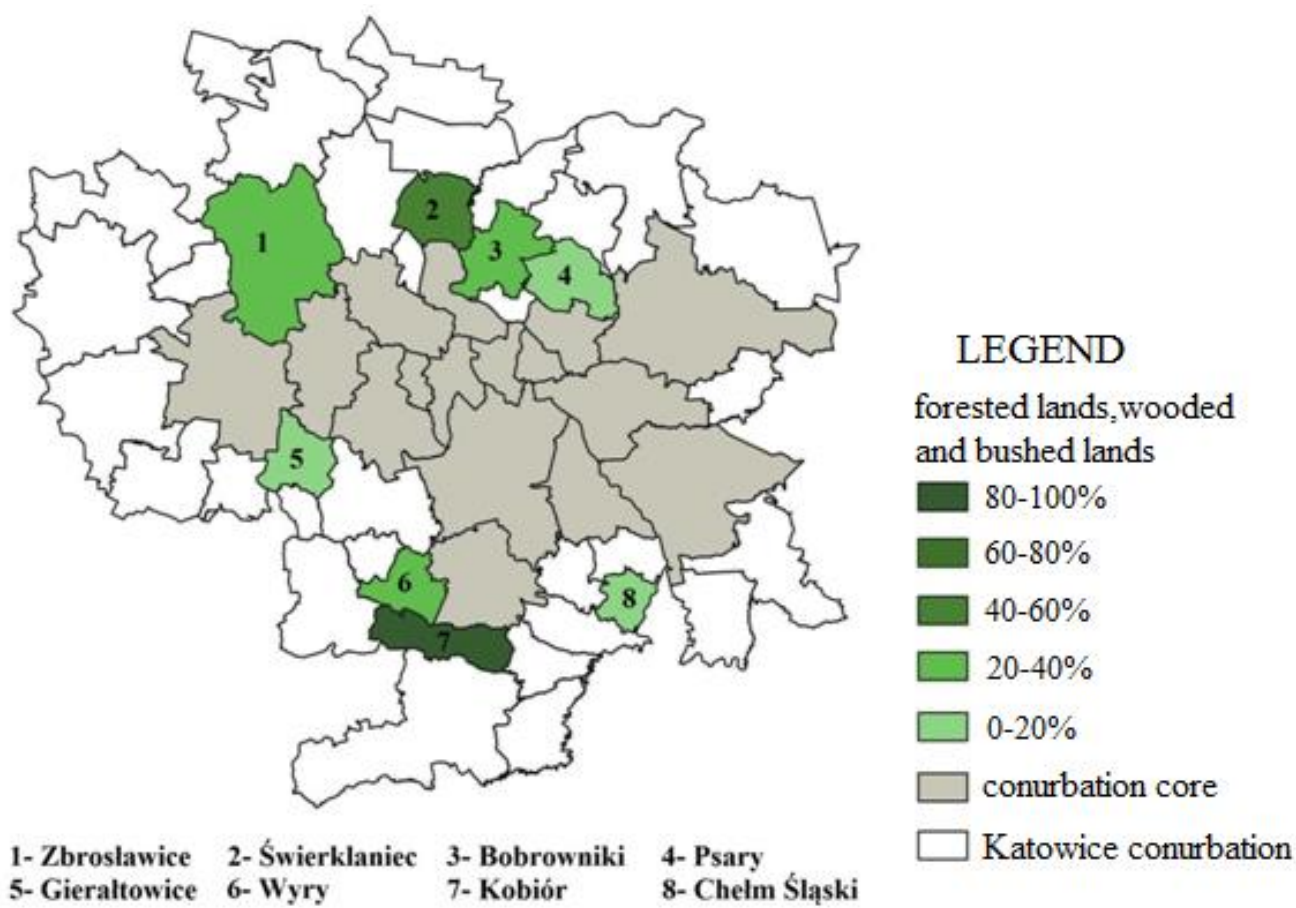

Figure 5. Participation of forested and wooded lands, 2014

Source: author's elaboration.

On the entire area of investigation there has been an increase in developed and urbanized lands. The smallest share in this form of land usage is in Kobibór, which is a result of the existing forest basin. In two municipalities the proportion of developed lands is on the level of 5 to $10 \%$, whereas in the remaining five municipalities $-10-15 \%$. The analysis done suggests that the highest level of urbanization is revealed by the rural municipalities located in the north of Katowice conurbation where the areas of a high concentration of new housing settlements are more visible (Fig. 6). In turn, the development of new housing settlements in the rural areas located in the south of Katowice conurbation is of a more uniform character. Of the developed and urbanized areas, the biggest changes occurred in the settlement areas, which gives evidence of the 
development of residential function and suburbanization. Examining suburban areas of big cities, as well as metropolitan areas in Poland, researchers point to the fact that since 1999 the population of rural municipalities has been increasing, predominantly due to a positive migration balance, whereas the inflow of population to rural areas has a permanent increasing tendency [19], [20], [25]. Analysing building permits issued in the examined 8 municipalities, one may come to a conclusion that in the period of 2003 2017 the examined area experienced the construction of 5,030 new buildings, which indicates the intense development of residential housing (predominantly one-family settlements) which is related to the dynamic increase of population in suburban areas [8], [16], [17], [29], [10]. Newly constructed residential settlements are predominantly erected by private persons, as well as developers. New buildings are constructed alongside passageways, due to a possibility of swift commuting to nearby urban areas, for financial, educational and service-based purposes. Convenient location is one of the main reasons of situating new housing estates [27]. Similarly, plots located in the vicinity of areas of significant natural values, e.g., forested areas and water reservoirs, are of high interest of investors. An increase of the participation of industrial lands in the total area in nearly all municipalities has been spotted. It results in the development of industrial functions and translates into an increase in non-cultural business activities.

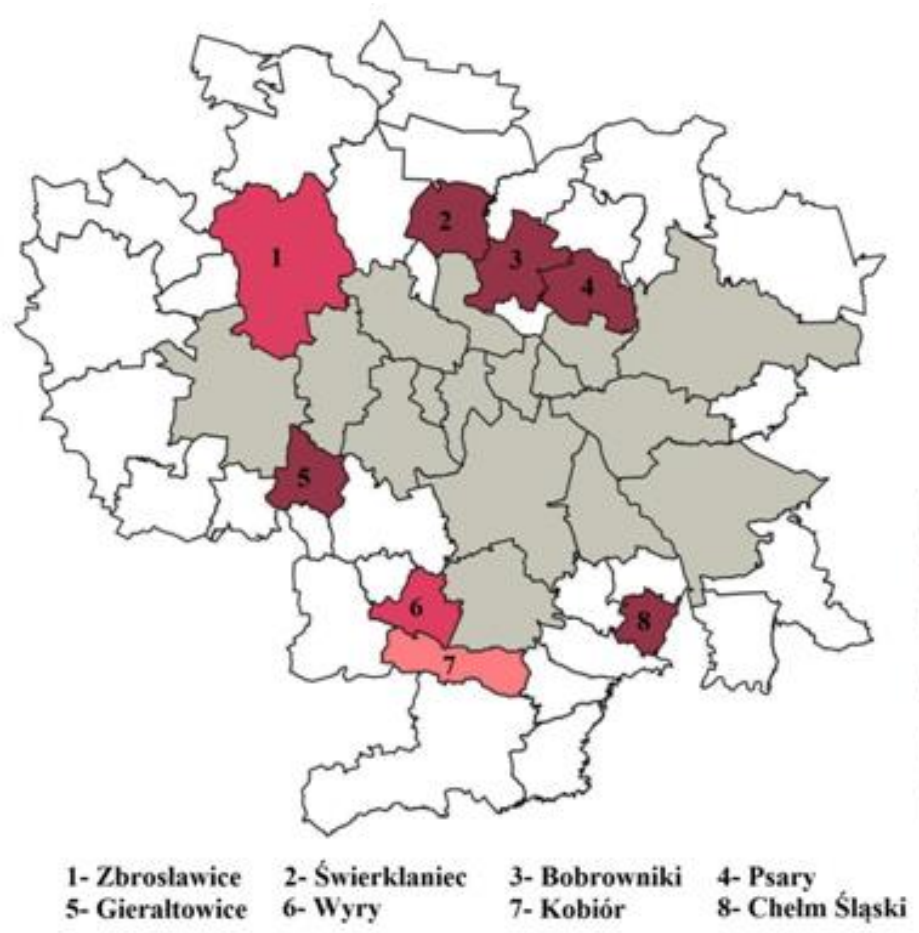

\section{LEGEND}

developed and urbanized lands

$15 \%$ i więcej

$\square 10-15 \%$

$\square-10 \%$

$0-5 \%$

conurbation core

Katowice conurbation

Figure 6. Share of developed in urbanized areas, 2014

Source: author's elaboration.

The changes of recreation and leisure areas have also occurred. The highest density of recreation areas is present in Świerklaniec and, partially, in Psary and Gierałtowice. The increase of recreation areas results from attractive natural conditions, and therefore the recreation function. The remaining forms of land usage in the investigated constitute an insignificant percentage of the total area. Wastelands are intended for, inter alia, developed lands, urbanized in the light of new residential housing, as well as industry. 


\section{CONCLUSIONS}

Spatial urbanization of rural areas manifests itself through the changes of land usage, morphology and physiognomy of villages. The occurrence of new urban functions in rural areas results in a decrease of agricultural lands which transformed into the areas of nonagricultural functions. The changes of rural areas in the aspect of production are an effect of urbanization processes [11]. Also the landscape of village from a rural character to a suburban one occurs [12]. It happens with the status of rural municipality maintained.

To sum up, the changes that have been occurring for nearly two decades of economic transformation in the usage of urban lands located in the vicinity of a large urban cluster might be noticed. The interaction of the conurbation of Katowice as a multi-core centre is not uniform in the aspect of space. The rural areas of favourable conditions for the development of agriculture are subject to spatial and functional transformation, however to a lesser extent that the rural areas of unfavourable conditions for agricultural production. In the course of time, agriculture in Silesia - a highly urbanized area - has been transforming. Individual agriculture and small farming has begun to decrease in significance, due to cost-effectiveness of production which was intended for own use and consumption. Therefore the rural areas have changed their purpose. In the areas of favourable natural conditions an agricultural function occurs, however of a specialized character. Large-scale farms of a specialized production character occur. They are occupied with a more specialized production, such as vegetable farming. Apart from agricultural activities, the horticulture of flowers and ornamental shrubs appeared.

On the areas of favourable conditions for agriculture, the process of suburbanization has been noticed, however of a lesser degree of intensity and advancement. In terms of natural attractiveness, the municipality of Kobibór stands out. It has the largest proportion of forest lands of a recreational character for its inhabitants. The same might be stated for Świerklaniec with a large park complex and water reservoirs. In the rural areas of unfavourable conditions for the development of agriculture, unoccupied and not developed areas are primarily intended for construction and, to a smaller degree, for industry and communication. These are the areas that are most likely to undergo the processes of urbanization, and therefore resemble the adjacent urban areas. The entire area of investigation undergoes suburbanization, nevertheless it occurs with different spatial intensity. Taking into account the usage of land, suburbanization occurs more strongly in the areas of unfavourable natural conditions where inhabitants depart from agricultural activities.

\section{REFERENCES}

[1] Duś E. Przemiany funkcjonalno - przestrzenne w obrzeżu Górnośląskiego Okręgu Przemysłowego na przykładzie wsi Bobrowniki [w:] Kamiński Z.J. ( pod red.) Urbanizacji wsi w obrzeżach miejsko - wiejskich, Katwice, pp 95 -102, 1995.

[2] Duś E. Uwarunkowania rozwoju rolnictwa w województwie śląskim, Acta Geographica Silesiana, UŚl WNoZ, Sosnowiec, No. 3, pp 19-26, 2008.

[3] Duvernoy I., Zambon I., Sateriano A., Salvati L. Pictures from the other side of the fringe: Urban growth and peri-urban agriculture in a post-industrial city (Toulouse, Frnace) Journal of Rural Studies, vol. 57, pp 25-35, 2018.

[4] Głaz M. Przekształcenia agrarne strefy podmiejskiej jako efekt oddziaływania miasta Wrocławia [w:] Słodczyk J., Klimek R. (red.): Przemiany przestrzeni miast i stref podmiejskich, Wydawnictwo Uniwersytetu Opolskiego, Opole, pp 153-166, 2006. 
[5] Holt-Jensen A. Transformation from state socialism to market economy; effects of agricultural production and rural landscapes in Estonia and Latvia, Acta Geobalcanica, vol. 1, issue 2, pp 6573, 2015.

[6] Kałamucka W., Kałamucki K., Kamińska A., Filipek M. Zmiany użytkowania terenu w Lublinie i jego najbliższym sąsiedztwie w ostatnim 40- leciu, Barometr Regionalny, vol. 4(30), pp $99-109,2012$.

[7] Kłosowski F. Usługi w restrukturyzującym się regionie tradycyjnym - przykład konurbacji katowickiej, Space-Society-Economy, Łódź, No. 08, pp 67- 78, 2008.

[8] Kłosowski F., Runge J. Migracje ludności w miastach województwa śląskiego w latach 19772006 [w:] red. Świątkiewicz W., Górnośląskie Studia Socjologiczne. Seria Nowa, Uniwersytet Śląski, Katowice, No. 1, pp 83-92, 2010.

[9] Krzysztofik K., Runge J., Spórna T. Delimitacja Regionu Górnośląsko - Zagłębiowskiej Metropolii „Silesia”, WNoZ UŚ, Sosnowiec, pp 49, 2011.

[10] Krzysztofik R., Kantor-Pietraga I., Runge A., Spórna T. Is the suburbanisation stage always important in the transformation of large urban agglomerations? The case of the Katowice conurbation, Geographia Polonica, Vol. 90, Issue 2, pp 71-85, 2017.

[11] Liszewski S. Przemiany przestrzeni wiejskiej w Polsce. Przyczyny i skutki-formy. Acta Universitatis Lodzinsis. Folia Geographica, Łódź, vol. 14, pp 7-19, 1991.

[12] Myga-Piątek U. Krajobrazy kulturowe. Aspekty ewolucyjne i typologiczne, Uniwersytet Śląski, Katowice, pp 406, 2012.

[13] Okuniewski J. Bezrobocie a pozarolnicze funkcje wsi. Zeszyty Naukowe AR w Krakowie, vol. 43, pp 11-17, 1995.

[14] Ouředníček M. Differential suburban development in the Prague urban region, Geografiska Annaler: Series B, Human Geography, 89(2), pp 111-126, 2007. DOI: 10.1111/j.14680467.2007.00243.x.

[15] Repaská G., Vilinovó K., Solcovó L. Trends in development of residential areas in suburban zone of the city of Nitra (Slovakia), European Countryside, 2, pp 287-301, 2017. DOI: 10.1515/euco-2017-0018.

[16] Runge J. Społeczno-gospodarcze oraz przestrzenne przejawy suburbanizacji w województwie śląskim [w:] red. Słodczyk J., Studia miejskie, No. 3: Procesy suburbanizacji w wybranych miastach Polski, Uniwersytet Opolski, Opole, pp 55-65, 2011.

[17] Runge J., Kłosowski F. Changes in population and economy in Śląskie voivodship in the context of the suburbanization procesess, Bulletin of Geography. Socio-economic series, UMK Torun, No. 16/2011, pp 89-106, 2011.

[18] Soczówka A. Zróżnicowanie struktury przestrzennej komunikacji miejskiej w konurbacji katowickiej, WNoZ UŚ, Sosnowiec, pp 243, 2012.

[19] Szymańska D., Biegańska J., Gil A. Rural areas in Poland in the context of changes in population age structure in 1996, 2001 and 2006, Bulletin of Geography, Socio-economic Series, vol. 12, pp 91-107, 2009.

[20] Szymańska D., Biegańska J. Obszary podmiejskie dużych miast w Polsce w świetle migracji stałych. In: Człowiek w przestrzeni zurbanizowanej, Soja M., Zborowski A., IGiGP UJ, Kraków, pp 83-98, 2011.

[21] Timár J., Váradi M. The Uneven Development of Suburbanisation During Transition in Hungary, European Urban and Regional Studies, 8(4), pp 349-360, 2001. DOI: 10.1177/096977640100800407.

[22] Tkocz M., Riley R. Local Respones to Changed Circumstances: Coalmining in Upper Silesia, Geojournal, 48, pp 279-290, 1999. 
[23] Tkocz M. Tradycyjny okręg przemysłowy z perspektywy 25-lecia funkcjonowania gospodarki rynkowej w Polsce. Przykład Górnośląskiego Okręgu Przemysłowego, Prace Komisji Geografii Przemysłu Polskiego Towarzystwa Geograficznego, vol. 29 (4), pp 112- 126, 2015.

[24] Vaishar A., Jakesova L., Naplavova M. Current problems in the South- Moravian rural landscape, European Countryside, No. 4, pp 265-281, 2011.

[25] Winiarczyk-Raźniak A., Raźniak P. Migracje wewnętrzne ludności w polskich obszarach metropolitalnych u progu XXI wieku, Uniwersytet Pedagogiczny, Kraków, pp 131, 2012.

[26] Zasada I., Loibl W., Köstl M., Piorr A. Agriculture under human influence: a special analysis of farming systems and land use in European rural- urban- regions, European Countryside, 1, pp 71-88, 2013. DOI: 10.2478/euco-2013-0005

[27] Zuzańska-Żyśko E., Petryszyn J. Rozmieszczenie nowych inwestycji mieszkaniowych w aglomeracji katowickiej [w:] red. Jażdżewska I., Współczesne procesy urbanizacji i ich skutki. XVIII Konwersatorium Wiedzy o Mieście, Wydawnictwo Uniwersytetu Łódzkiego, Łódź, pp 361-371, 2005.

[28] Zuzańska-Żyśko E., 2014: The real estate market in the Upper-Silesian metropolitan area, Procedia - Social and Behavioral Sciences, 120, s. $374-385$.

[29] Zuzańska-Żyśko E., Pytel S., Koman W. Suburbanization in Postindustrial Area. Case Study of The Silesia Metropolitan Region [w:] Efe R., Cürebal I., Lévai L. (red.), GeoMed 2016. $4^{\text {th }}$ International Geography Symposium. Book of Proceedings, Kemer, Antalya (Turkey), pp 835849, 2016. 